\title{
Implementasi program pembelajaran dalam lingkungan berbahasa Inggris pada playgroup and kindergarten
}

\author{
Fitriani Kimalasari \\ Jurusan Pendidikan Anak Usia Dini, Fakultas Pendidikan, Universitas Negeri Yogyakarta. \\ Jalan Colombo No. 1, Karangmalang, Yogyakarta 55281, Indonesia \\ E-mail: fitriani.kimalasari2015@student.uny.ac.id
}

\begin{tabular}{ll}
\hline \hline ARTICLE INFO & ABSTRACT \\
\hline \hline Article history: & Penelitian ini untuk mendeskripsikan program pembelajaran dalam \\
Received: $21-8-2019 ;$ & lingkungan berbahasa Inggris yang terdiri atas: perencanaan pembelajaran, \\
Revised: $3-9-2019 ;$ & pelaksanaan pembelajaran, dan evaluasi pembelajaran di kelas Kidergarten \\
Accepted: $3-9-2019$ & Ananda Mentari Playgroup and kindergarten Bumijo Yogyakarta. Penelitian ini \\
& menggunakan metode deskriptif dengan pendekatan kualitatif. Subjek dari \\
Keywords: & penelitian ini yaitu 1 kepala sekolah, 1 guru kindergarten, 1 tenaga \\
program pembelajaran; & kependidikan, 1 trainer, dan 1 wali murid. Objek penelitian yaitu program \\
lingkungan berbahasa & pembelajaran dalam lingkungan berbahasa Inggris. Teknik pengumpulan data \\
Inggris; anak usia dini; & yang dilakukan menggunakan wawancara terstruktur, observasi, dokumentasi \\
learning program; English & serta catatan lapangan. Instrument penelitian menggunakan model interaktif \\
language environment; early & yang meliputi reduksi data, penyajian data dan penarikan kesimpulan. \\
childhood & Keabsahan data penelitian diuji dengan menggunakan triangulasi teknik dan \\
& triangulasi sumber. Hasil penelitian menunjukan bahwa: (1) Perencanaan \\
& program pembelajaran dalam lingkungan berbahasa Inggris menggunakan \\
& kurikulum adaptasi dari 4 negara, (2) Pelaksanaan kegiatan pembelajaran, \\
& metode dan materi untuk anak didik menggunakan bahasa Inggris dengan \\
& jenis kegiatan eksploratif. (3) Evaluasi pembelajaran dilakukan menggunakan \\
checklist dan anekdot sesuai usia perkembangan anak. (4) Faktor pendukung & program pembelajaran adalah kerjasama antar guru dan parents club. (5) \\
& Faktor penghambat program pembelajaran adalah persaingan dengan sekolah \\
& lain, lokasi tidak strategis, dan sulit mencari guru yang memenuhi kriteria. \\
\hline \hline
\end{tabular}

The purpose of this research is to describe a learning program based on English-language environment which consist of study planning, implementing, and evaluating that applied in kindergarten class at Ananda Mentari Playgroup and Kindergerten Bumijo Yogyakarta. This study requires descriptive method and qualitative approach. The subjects of this research are one of headmaster, one of kindergarten teacher, one trainer, and one of student guardian. The object of this study is about learning in an English-language environment. The data collection techniques used in this research are such as structured interviews, observations, documentations also field notes. The instrument has a interactive model consist of data reduction, data presentation, and data conclusion. This study shows that (1) the learning program based on English-language environment planning is adopted from 4 countries curriculums, (2) the english based study implementation, methods, and materials for the students are using a more explorative activities, (3) class evaluation used by checklist and anecdote suited for children growth, (4) the supporting factors of the learning program are cooperation between teachers and parents clubs. (5) the inhibiting factor of the learning program is competition with other schools, the location is not strategic, and it is difficult to find teachers who meet the criteria. 


\section{PENDAHULUAN}

Bangsa Indonesia memiliki cita-cita yang hendak dicapai dalam berbagai bidang, baik dalam bidang sosial, ekonomi, ataupun pendidikan, salah satu cita-cita bangsa Indonesia adalah mencerdaskan kehidupan bangsa. Cita-cita bangsa Indonesia terkandung dalam pembukaan UUD 1945 (Muafiah, 2016, p. 63).

Penyelenggaraan pendidikan yang dirintis mulai dari Pendidikan Anak Usia Dini (PAUD) hingga Perguruan Tinggi (PT) merupakan upaya mewujudkan cita-cita bangsa. Pendidikan untuk anak usia dini saat ini masih dipandang sebelah mata oleh sebagian besar masyarakat. Masyarakat menganggap bahwa PAUD sebatas jembatan menuju pendidikan ke jenjang selanjutnya (Tirtaraharja dan La Sulo, 2005: 76). PAUD merupakan jenjang pendidikana awal yang sangat penting sehingga dapat dijadikan salah satu bekal bagi seseorang agar berhasil dan sukses dalam kehidupannya dimasa mendatang.

Pertumbuhan dan perkembangan yang terjadi pada usia dini merupakan pondasi awal (Evi Muafiah, 2016: 64), maka sewajarnya pendidikan anak di usia tersebut lebih diperhatikan. Pakar pendidikan meyakini bahwa masa kanak- kanak yang bahagia merupakan dasar keberhasilan di masa mendatang (Yuliani Nurani dan Bambang Sujiono, 2010: 21), oleh karena itu terdapat satu prinsip yang perlu diperhatikan dalam pendidikan di Taman Kanak-kanak (TK), yaitu belajar sambil bermain dan bermain seraya belajar (Wuryani Tri Astuti, 2016: 258). Sejalan dengan pendapat tersebut, agar pertumbuhan dan perkembangan anak tercapai secara optimal dibutuhkan situasi dan kondisi yang kondusif saat pemberian stimulasi serta upaya pendidikan yang sesuai dengan kebutuhan dan minat anak. Suasana belajar yang menyenangkan adalah syarat mutlak yang diperlukan supaya anak yang dapat merasakan bahwa belajar adalah kegiatan yang menyenangkan dapat memicu rasa ingin tahu yang besar, dan berpengaruh pada kesuksesan belajarnya dimasa mendatang (Eva Rabbianty, 2015: 84).

Anak usia dini dapat tumbuh dan berkembang secara optimal jika mendapat stimulasi atau rangsangan pendidikan yang tepat. Pada masa yang sering disebut masa keemasan (golden age), otak berkembang sangat pesat mencapai $80 \%$ dan terus meningkat terhitung sejak anak dilahirkan sampai dengan usia enam tahun (Suyadi, 2010, pp. 23-24). Masa ini dapat diartikan sebagai masa peka terjadi pematangan fungsi-fungsi fisik dan psikis sehingga anak siap merespon dan melaksanakan tugas-tugas sesuai perkembangannya (Yuliani Nurani dan Bambang Sujiono, 2010, p. 20).

Suasana belajar yang menyenangkan dan menarik bisa meningkatkan lima aspek perkembangan yang meliputi aspek perkembangan NAM (nilai, moral, dan agama), aspek perkembangan kognitif, aspek perkembangan fisik motorik, aspek perkembangan sosial emosional dan aspek perkembangan bahasa (Paramita Desintya 2015: 2). Aspek bahasa menjadi salah satu titik fundamental bagi perkembangan anak, dikarenakan bahasa merupakan salah satu alat yang digunakan sebagai alat komunikasi untuk berhubungan dengan orang lain.

Welton \& Mallon dalam Moeslichatoen (2004: 18), menjelskan bahwa bahasa merupakan bentuk utama dalam mengekspresikan pikiran dan pengetahuan bila anak mengadakan hubungan dengan orang lain. Anak yang sedang tumbuh dan berkembang mengkomunikasikan kebutuhan, pikiran dan perasaannya melalui bahasa dengan kata-kata, sehingga dapat disimpulkan bahwa bahasa menjadi tiang untuk berkomunikasi dengan orang lain di lingkungan kehidupannya.

Anak usia dini memiliki dua tahapan dalam pemerolehan bahasa dini yaitu pemerolehan bahasa pertama dan pemerolehan bahasa kedua (Wina Sanjaya, 2009: 37). Pemerolehan bahasa pertama adalah bahasa yang diperoleh dan dipahami anak dari kehidupan dan berkomunikasi di lingkungannya. Bahasa ibu merupakan bahasa pertama, karena ibulah yang pertama berkomunikasi, berinteraksi, dan mengajarkan bahasa kepada anak (Wina Sanjaya, 2009: 57). Bahasa kedua anak di Indonesia umumnya adalah bahasa Indonesia atau bahasa asing. Bahasa Indonesia diperoleh anak dalam lingkungan kehidupannya dan dari pendidikan formal di sekolah. Sedangkan pemerolehan bahasa asing pada umumnya melalui pendidikan informal maupun formal (Suhartono, 2005: 85).

Bahasa Inggris dianggap sebagai salah satu tolak ukur keberhasilan seseorang yang semakin dirasakan di negara-negara yang tidak menggunakan bahasa Inggris sebagai bahasa komunikasi seharihari (Brewster, Ellis \& Girard, 2002). Hal ini menjadi salah satu faktor yang membuat semakin meluasnya kebutuhan akan pembelajaran bahasa Inggris sebagai bahasa asing, atau yang sering disebut sebagai English as a Foreign Language (EFL) di Indonesia. Bahasa Inggris mulai diajarkan pada 
tingkat Sekolah Menengah Pertama (SMP), bahkan saat ini juga mulai diajarkan di tingkat pendidikan yang lebih rendah yaitu Sekolah Dasar (SD), serta banyak pula yang memulai mengenalkan bahasa Inggris di tingkat PAUD, yaitu TK ataupun Kelompok Bermain (KB) (Yuliariatiningsih, 2013).

Program pengenalan bahasa Inggris pada anak usia dini saat ini mulai dilakukan dengan berbagai kegiatan dalam pembelajaran yang bermakna, hal ini terjadi karena proses pengenalan bahasa Inggris di TK dimulai dari pengenalan dan penggunaan kosakata bahasa Inggris yang mulai dikenalkan dengan konteksnya. Penggunaan bahasa Inggris tidak hanya sekedar memorisasi dari translasi kata-kata dalam bahasa Indonesia, terjadinya hal demikian dikarenakan persepsi guru yang menganggap belajar bahasa asing sebagai hal yang menarik bagi usia dini (Winti Anantia, 2015) dan kemampuan guru yang terus dikembangkan dalam memberikan pembelajaran bahasa Inggris sebagai bahasa asing bagi anak usia dini.

Penggunaan bahasa Inggris di Indonesia banyak dijumpai seperti di film, penamaan tempat, menu makanan, dan iklan, namun bahasa Inggris di Indonesia tidak memegang peranan sebagai bahasa nasional ataupun bahasa kedua. Bahasa Inggris di Indonesia berperan sebagai bahasa asing, dimana bahasa tersebut tidak digunakan sebagai bahasa resmi negara maupun percakapan sehari-hari oleh sebagian besar warganya (Paul, 2007: 1), sehingga bahasa Inggris di Indonesia sulit untuk diterapkan dalam kehidupan sehari hari (Paul, 2007: 2).

Anak yang berada dalam masa emas akan lebih cepat belajar bahasa asing dari pada orang dewasa (Santrock. 2007: 313). Mustafa (2007: 20) menambahkan bahwa anak yang menguasai bahasa asing memiliki kelebihan dalam hal intelektual yang fleksibel, keterampilan akademik, berbahasa dan sosial. Anak akan memiliki kesiapan memasuki suatu konteks pergaulan dengan berbagai bahasa dan budaya, sehingga ketika dewasa anak akan menjadi sumber daya manusia yang berkualitas dan berperstasi. Keterampilan berbahasa memiliki dua sifat, yakni bahasa reseptif dan produktif (Nurbiana Dhieni, 2007: 19). Keterampilan berbahasa reseptif adalah kemampuan menerjemahkan kembali kodekode kebahasaan yang bermakna dalam komunikasi baik lisan maupun tertulis. Suryana (2016: 127) memiliki pendapat yang serupa bahwa behasa yang bersifat reseptif merupakan bahasa yang diterima dan dimengerti, sedangkan bahasa produktif atau ekspresif merupakan bahasa yang dinyatakan, contoh bahasa reseptif adalah ketika mendengarkan dan membaca, sedangkan bahasa produktif adalah ketika berbicara dan menulis.

Ananda Mentari Playgroup and kindergarten Bumijo, merupakan salah satu sekolah untuk anak usia dini yang menggunakan bahasa Inggris secara total dalam kegiatan pembelajarannya sehari-hari. Anak-anak dari kelas baby and toddler hingga Kindergarten tidak hanya sebatas memahami dan menyerap bahasa Inggris yang disampaikan guru. Anak-anak juga mampu mengungkapkan atau menyatakan bahasa Inggris melalui komunikasi verbal secara lancar, sehingga dapat diketahui bahwa Ananda Mentari Playgroup and kindergarten Bumijo menstimulasi perkembangan bahasa Inggris bagi anak-anak di kelas baby and toddler hingga Kindergarten bukan sekedar keterampilan reseptif saja namun juga bahasa ekspresifnya.

Anak-anak di kelas baby and toddler hingga Kindergarten merupakan warga negara Indonesia yang ketika berada di rumah menggunakan bahasa ibu atau bahasa Indonesia. Guru kelas baby and toddler hingga Kindergarten juga merupakan warga negara Indonesia yang memiliki latar belakang pendidikan dari berbagai jurusan, sehingga dapat dikatakan bahwa tidak ada English native speaker di Ananda Mentari Playgroup and Kindergarten Bumijo. Ketika peneliti melakukan observasi di kelas kindergerten anak mampu berbicara mengguakan aksen standar bahasa Inggris American.

Ananda Mentari Playgroup and Kindergarten Bumijo menerapkan kegiatan belajar yang khas dengan menggunakan bahasa Inggris secara total dalam kegiatan pembelajaran dan adanya kegiatan eksploratif untuk memperluas pengetahuan anak tentang tema pembelajaran yang sedang di pelajari, pelaksanaan kegiatan eskploratif juga dilakukan dalam komunikasi menggunakan bahasa Inggris sehingga kegiatan pembelajaran lebih bermakna tidak hanya sebatas menghafal saja. Implementasi program lingkungan berbahasa Inggris seperti yang diterapkan di Ananda Mentari Playgroup and kindergarten Bumijo khususnya di kelas kindergarten atau TK belum pernah di teliti sebelumya, sehingga peneliti ingin mengkaji labih dalam melalui penelitian berjudul "Implementasi Program Pembelajaran dalam Lingkungan Berbahasa Inggris di Ananda Mentari Bumijo Playgroup and Kindergarten Bumijo Yogyakarta”. 


\section{METODE}

Penelitian ini merupakan penelitian deskriptif dengan pendekatan kualitatif. Waktu pelaksanaan untuk penelitian yaitu pada bulan April-Mei 2019. Penelitian ini dilakukan di Ananda Mentari Playgroup and kindergarten Bumijo Yogyakarta yang beralamatkan di Jalan Bumijo Lor 11A Yogyakarta. Subjek dalam penelitian adalah satu kepala sekolah, satu guru kelas, satu trainer, dan satu wali murid.

Dalam penelitian ini, peneliti mengamati perencanaan, pelaksanaan, evaluasi, faktor pendukung dan penghambat implementasi program pembelajaran dalam lingkungan berbahasa Inggris pada anak kelompok kindergarten. Peneliti mengamati pembelajaran mulai dari persiapan, pelaksanaan, dan evaluasi kegiatan pembelajaran harian anak

Peneliti sebagai pengumpul data menggunakan intrumen penelitian berupa pedoman observasi yang dilakukan secara terus terang sehingga sebjek mengetahui akan penelitian yang dilakukan, kemudian dengan pedoman observasi dan wawancara, serta catatan lapangan langsung ketika penelitian berlangsung agar data yang diperoleh lebih luas. Teknik pengumpulan data yaitu observasi, wawancara, dokumentasi dan catatan lapangan.

Penelitian ini menggunakan teknik analisis data deskriptif kualitatif. Analisis data dilakukan dengan menjabarkan ke dalam unit-unit, melakukan analisis terhadap data yang penting, menyanjikan data sesuai dengan masalah penelitian dalam bentuk laporan, dan membuat suatu kesimpulan agar hasil yang telah didapatkan menjadi lebih mudah dipahami. Data penelitian ini menggunakan analisis berupa model interaktif dari Miles and Huberman (Sugiyono, 2010: 246). Pada analisis ini terbagi atas 4 komponen sebagai berikut:

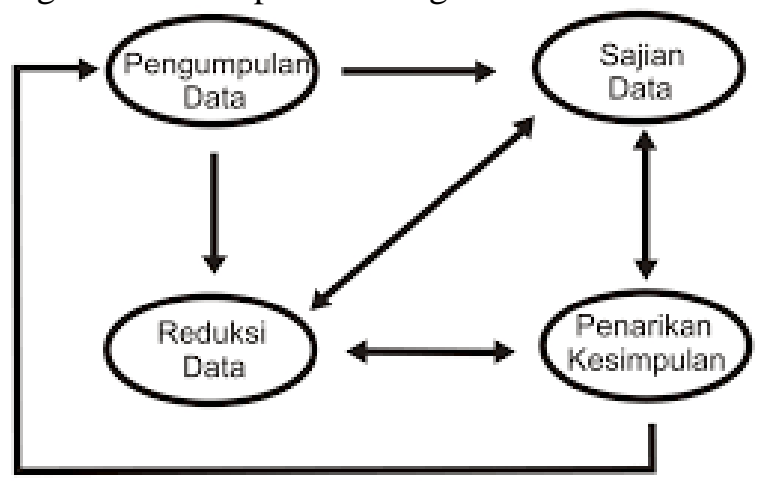

Gambar 1. Model interaktif dari Miles dan Huberman (Sugiyono, 2010: 246).

\section{HASIL DAN PEMBAHASAN}

\section{Hasil}

Perencanaan Program Pembelajaran

Perencanaan program pembelajaran yang dilakukan bertujuan untuk mempersiapkan kegiatan pembelajaran di mulai dari perencanaan setting sekolah dan in house training, perencanaan kurikulum, program semester, serta rancangan pembelajaran mingguan. Perencanaan tersebut dilakukan agar pelaksanaan kegiatan pembelajaran dalam lingkungan berbahasa Inggris dapat berjalan secara optimal.

Pelaksanaan Program Pembelajaran

Pelaksanaan pembelajaran dilaksanakan dengan berbagai metode pembelajaran seperti story telling, role play, art and craft, games, serta music and movement, dalam pelaksanaan kegiatan pembelajran harian tidak semua metode diterapkan, hanya metode yang sesuai dengan jenis kegiatan harian saja yang akan digunakan. Kegiatan pembelajaran di Ananda Mentari Playgroup and kindergarten dibagi menjadi lima kegiatan, yaitu: kegiatan awal, kegiatan inti, restroom break and snack time, kegiatan akhir dan lunch. Dalam pelaksanaannya mulai dari kegiatan awal hingga lunch di laksanakan dengan bahasa Inggris secara total sebagai bahasa pengantarnya. 
Evaluasi Program pembelajaran

Bentuk penilaian kepada anak yang dilakukan oleh guru di Ananda Mentari Playgroup and Kindergarten dilakukan dalam bentuk checklist dan anekdot, namun penilaian dalam bentuk anekdot tidak dilakukan secara rutin. Evaluasi anak mengenai pemahamannya terhadap materi yang sudah diterima dapat diperoleh melalui raport harian, mingguan, tengah semester, dan akhir semester.

Raport harian berisikan kegiatan yang dilakukan dan apa saja yang telah dikonsumsi oleh anak. Raport mingguan adalah laporan tentang hasil belajar anak yang mengikuti kegiatan pembelajaran selama satu minggu. Raport tengah semester berupa kegiatan puncak tema atau yang diistilahkan sebagai exit point di Ananda Mentari Playgroup and Kindergarten, jenis kegiatan exit point tergantung tema yang sedang dilaksanaan. Raport akhir semester dilaksanakan dalam kegiatan presentation day dimana anak akan mempresentasikan informasi yang telah diterima selama satu semester dan menampilkannya dalam kegiatan bernyanyi, drama, serta gerak dan lagu. Kegiatan pembelajaran yang dilaksanakan bertujuan utuk merangsang perkembangan anak, serta meningkatkan keterampilan berbahasa anak seperti menyimak (listening), berbicara (speaking), membaca (reading), dan menulis (writing).

\section{Pembahasan}

\section{Perencanaan Program Pembelajaran}

Berdasarkan hasil penelitian, Ananda Mentari Playgroup and kindergarten telah melakukan perencanaan program pembelajaran dalam lingkungan berbahasa Inggris dengan merancang dan mempersiapkan segala sesuatu sebelum pelaksanaan program pembelajaran berjalan. Bentuk kegiatan perencanaan di Ananda Mentari adalah dengan adanya setting sekolah untuk mendukung pembelajaran anak, In House Training bagi tenaga kependidikan, dan penyusunan kurikulum, program semester serta RPPH yang dilakukan dalam Bahasa Inggris sebagai penekanan bahwa kegiatan pembelajaran di Ananda Mentari menggunakan bahasa Inggris.

Perencanaan program ini memperhatikan komponen-komponen pendidikan yang menunjang terlaksananya program pembelajaran.

Perencanaan program pembelajaran dalam lingkungan berbahasa Inggris di Ananda Mentari Playgroup and kindergarten sudah sesuai dengan pendapat Aswarni Sujud (1987: 10) bahwa perencanaan merupakan kegiatan menentukan tujuan dan merencanakan kegiatan yang akan dilakukan.

Perencanaan kurikulum Ananda Mentari Playgroup and kindergarten merupakan gabungan dari beberapa kurikulum luar negeri yang diadaptasi dan digabungkan dengan kurikulum pemerintah sehingga lahirlah kurikulum khas Ananda Mentari Playgroup and kindergarten. Kurikulum Ananda Mentari Playgroup and kindergarten mencakup di dalamnya program pembelajaran yang dilaksanakan dalam lingkungan berbahasa Inggris yang berlaku untuk tenaga pendidik dan anak didik. Perencanaan kurikulum juga mencakup perencanaan program semester dan rancangan pembelajaran mingguan yang di dalamnya memuat rincian kegiatan pembelajaran harian menurut tema dan sub-tema yang berlangsung.

Anak usia 4-5 tahun memasuki masa berkembang pesatnya penguasaan tugas pokok dalam berbicara yaitu menambah kosakata, menguasai penambahan pengucapan kata dan menggabungkan kata menjadi kalimat (Hurlock, 2011: 113). Hal ini sejalan dengan pendapat dari kepala sekolah Ananda Mentari Playgroup and kindergarten yang menyatakan bahwa dalam lima tahun pertama anak mampu mempelajari banyak bahasa. Hal tersebut menjadi landasan Ananda Mentari Playgroup and kindergarten menggunakan bahasa Inggris dalam komunikasi di lingkungan sekolah.

Perencanaan program pembelajaran dalam lingkungan berbahasa Inggris dipengaruhi oleh kualitas lingkungan bahasa itu sendiri, karena hal tersebut lingkungan memegang peran penting dalam menentukan keberhasilan pembelajar dalam mempelajari bahasa kedua (Purba, 2013: 16). Ananda Mentari Playgroup and kindergarten sudah memperhatikan lingkungan berbahasa dengan memberikan poster dan tulisan- tulisan dalam bahasa Inggris yang dapat dilihat oleh anak setiap harinya, sehingga secara tidak langsung mendukung pengembangan kemampuang berbahasa 
Inggris anak. selain itu Ananda Mentari Playgroup and kindergarten juga melakukan setting terhadap ruang kelas dengan menghiasnya sesuai tema pembelajaran yang dilaksanakan dalam bahasa Inggris.

Pelaksanaan Program Pembelajaran

Pembelajaran bahasa Inggris untuk anak usia dini dapat dilaksanakan dengan menerapkan program pembelajaran seperti yang dijabarkan oleh Beverly Otto (2015: 100), yaitu dengan program pendekatan submersi. Pendekatan submersi memiliki anggapan bahwa pembelajar bahasa kedua akan secara bertahap memperoleh bahasa Inggris melalui partisipasinya dalam lingkungan khusus berbahasa Inggris. Dengan partisipasinya dalam lingkungan ini, diharapkan mereka mampu memperoleh pengetahuan bahasa Inggris karena telah mendengar dan menggunakannya dalam berbagai kegiatan pembelajaran dan berbagai situasi kondisi. Pedekatan submersi digambarkan sebagai pendekatan yang 'membenamkan atau menenggelamkan' pembelajar dalam suatu kondisi komunikasi dengan bahasa asing sehingga tanpa disadari terjadi perkembangan secara alami dalam aspek bahasanya.

Ananda Mentari Playgroup and kindergarten melaksanakan program pembelajaran dalam lingkungan berbahasa Inggris dengan pendekatan submersi, dimana anak didiknya ditempatkan dalam kondisi dimana mereka berada dalam lingkungan yang kegiatannya menggunakan bahasa Inggris secara total. Dengan diterapkannya program pembelajaran dengan pendekatan submersi ini anak akan terbawa dengan kondisi lingkungan yang menggunakan bahasa Inggris dalam komunikasinya, sehingga tanpa disadari anak akan mengalami perkembangan dalam aspek bahasanya terutama dalam bahasa Inggrisnya.

Pelaksanaan program pembelajaran di Ananda Mentari Playgroup and kindergarten juga memperhatikan prinsip-prinsip pembelajaran bagi anak usia dini yang tedapat di Direktorat Pembinaan PAUD (Helmawati, 2015: 49) bahwa pendidikan dilaksanakan dengan berorientasi pada kebutuhan anak, hal ini ditandai dengan adanya sikap menghargai terhadap hasil karyanya dengan mengapresiasi sehingga anak merasa diakui keberadaannya. Lalu pembelajaran juga dilakukan berdasarkan tingkatan perkembangan anak, ditunjukan dengan adanya pembagian tugas ketika membuat poster bersama, anak yang lebih muda diberikan tugas yang lebih mudah dibanding anak yang lebih tua.

Prinsip lain yang diterapkan adalah kegiatan pembelajaran yang diterapkan dengan metode bermain sehingga memberikan rasa senang bagi anak. Dalam kegiatan eksplorasi guru juga melaksanakan pembelajaran yang berpusat kepada anak dengan memberikan kesempatan kepada anak untuk menentukan pilihannya sendiri ketika bereksperimen. Anak-anak di Ananda Mentari Playgroup and kindergarten juga dirangsang untuk berkreatifitas dan berinovasi dalam kegiatan pembelajaran. Dalam pembehasan tentang water cycle anak diberikan kesempatan untuk membuat karya tentang water cycle tanpa memberikan contoh hasil karya yang sudah jadi kepada anak sehingga anak lebih bebas berkreasi sesuai dengan keinginannya.

Walaupun program pembelajaran di Ananda Mentari Playgroup and kindergarten dilakukan dalam bahasa Inggris, anak-anak tetap diberikan pembelajaan sesuai dengan kondisi sosial budaya. Misal ketika memperingati hari Kartini, anak akan dikenalkan tenatang sosok Kartini agar mengetahui jasa-jasa beliau serta dikenalkan pula mainan dan makanan tradisional agar anakanak tetap mengenal warisan budanyanya. Prinsip-prinsip pembelajaran anak usia dini di Ananda Mentari Playgroup and kindergarten di terapkan mulai dari kegiatan awal sampai kegiatan akhir.

Pemahaman tentang bahasa reseptif dan ekspresif dipaparkan oleh Suryana (2016: 127) yang menyatakan bahwa keterampilan bahasa ada yang bersifat reseptif merupakan bahasa yang dimengerti dan diterima, dan ekspresif merupakan bahasa yang dinyatakan. Pemahaman tentang bahasa reseprif dan ekspresif di Ananda Mentari Playgroup and Kindergerten dilakukan dalam kegiatan pembelajaran. Bahasa reseptif tampak pada kegiatan diskusi atau drilling kosakata baru. Sedamgkan bahasa ekspresif tampak ketika anak bernyanyi, role play atau story telling.

Evaluasi Program Pembelajaran

Melalui program pembelajaran dalam lingkungan berbahasa Inggris di Ananda Mentari Playgroup and kindergarten tujuan pendidikan sekolah sudah tercapai, bahkan terjadi 
peningkatan kemampuan berbahasa Inggris yang dialami oleh warga sekolah, selain itu anak juga mampu berbicara dengan bahasa Inggris dan kemampuannya untuk menyesuaikan diri di tempat lain untuk membedakan kapan penggunaan bahasa Indonesia dan kapan harus digunakan bahasa Inggris.

Evaluasi kurikulum di Ananda Mentari Playgroup and kindergarten terletak pada belum adanya pencatatan sistematis untuk program semester dan RPPH. Sehingga untuk mengumpulkan data dokumentasi tentang tema dan kegiatan apa saja yang sudah dilaksanakan menjadi lebih sulit, namun seperti yang telah dipaparkan oleh Suyanto (2007) bahwa kegiatan belajar bahasa Inggris di Ananda Mentari Playgroup and kindergarten sudah mencakup kompetensi dan keterampilan berbahasa seperti menyimak (listening), berbicara (speaking), membaca (reading), dan menulis (writing) yang di lakukan dalam pelaksanaan program pembelajaran.

Evaluasi tenaga pendidik dan tenaga kependidikan di Ananda Mentari Playgroup and kindergarten adalah penggunaan bahasa Inggris yang belum mutlak digunakan di luar jam pembelajaran karena masih didapati beberapa tenaga pendidikan yang melakukan komunikasi dalam bahasa Indonesia.

Evaluasi fasilitas pendidikan di Ananda Mentari Playgroup and kindergarten yaitu sarana dan prasarana yang sudah mendukung dalam pelaksanaan program pembelajaran. Fasilitas ekstrakuriluler yang ditawarkan oleh Ananda Mentari Playgroup and kindergarten juga dapat meningkatkan kemampuan anak dibidang akadmik dan non akademik.

Evaluasi pembelajaran di Ananda Mentari Playgroup and kindergarten juga sudah berjalan dengan baik, ditandai adanya evaluasi yang dilakukan oleh guru dalam jangka waktu harian, mingguan, tengah semester, dan diakhir semester.

Faktor Pendukung dan Pengahambat

Faktor pendukung pelaksanaan pembelajaran adalah teamwork guru yang mampu berkerjasama dan melengkapi kekurangan satu sama lain dalam pelaksanaan program pembelajaran, supplier buku sebagai salah satu pihak yang membatu menyediakan materi pembelajaran untuk anak, dan yang terakhir adalah guru ekskul. Faktor penghambat pelaksanaan pembelajaran yaitu adanya kesulitan mencari narasumber yang ahli dalam suatu bidang, dan mampu berbahasa Inggris untuk menyampaikan informasi kepada anak.

Faktor pendukung pelaksanaan program adalah kerjasama dari berbagai pihak seperti sanggar tari, dukungan dari keluarga guru, dan parents club. Parents club merupakan salah satu elemen yang menunjang program pemebelajaran dalam lingkungan berbahasa Inggris yaitu kegiatankegiatan agenda yang dilaksanakan untuk mendukung kegiatan anak didik oleh organisasi orang tua. Tidak hanya mendukung kegiatan yang bersifat akademik, Parents club juga mendukung kegiatan sekolah yang bersifat non- akademik seperti bakti sosial.

Parents club di Ananda Mentari memiliki agenda rutin yang yang dilakukukan. Agenda tersebut meliputi bakti sosial, family gathering, kids festival, dan buka bersama. Kegiatan bakti social yang dilakukan dilakukan untuk membantu sesama yang membutuhkan, selain membantu yang membutuhkan lewat kegiatan bakti sosial ini juga anak akan menampilkan pentas seni dimana apa yang ditampilkan sesuai dengan tema yang sedang berlangsung. Kegiatan selanjutnya adalah family gathering, kegiatan ini mirip dengan kegiatan outbond dimana warga sekolah bersama dengan wali anak didik pergi bersama untuk mempererat tali persaudaraan. Family gathering biasanya diadakan ketika tutup semester.

Kegiatan rutin yang ke tiga adalah kids festival, kids festival merupakan kegiatan yang menyerupai market day dimana anak akan mencoba melakukan simulasi jual beli dengan uang kertas dan orang tua berperan sebagai pembeli. Kegiatan rutin yang terakhir adalah buka bersama untuk merayakan bulan Ramadhan bagi yang merayakan. Selain agenda rutin di atas parents club juga memiliki agenda rapat ketika akan mengadakan kegiatan sekolah yang melibatkan wali anak didik.

Sedangkan faktor penghambat pelaksanaan program adalah persaingan yang terjadi dengan sekolah berlabel agama, lokasi yang tidak mendukung, dan permasalahan dengan Diknas serta kesulitan mencari guru yang mampu memenuhi kriteria untuk menjadi tenaga pendidik di Ananda Mentari Playgroup and kindergarten. 


\section{SIMPULAN}

Berdasarkan hasil penelitian dan pembahasan penelitian Implementasi pembelajaran dalam lingkungan berbahasa Inggris di Ananda Mentari Playgroup and kindergarten, maka dapat disimpulkan sebagai berikut:

1. Perencanaan pembelajaran yang berupa program semester, rencana pembelajaran mingguan dan tema disusun oleh divisi guru dan bagian kurikulum dengan persetujuan kepala sekolah. Kurikulum yang diterapkan yaitu kurikulum adaptasi dari beberapa kurikulum luar negeri yang telah disesuaikan dengan kurikulum yang berlaku di Indonesia saat ini.

2. Pelaksanaan pembelajaran dilakukan dengan urutan kegiatan pembuka, kegiatan inti, restroom break and snack time, kegiatan penutup serta lunch. Dalam proses pembelajaran yang diberikan, kegiatan pembelajaran telah disesuaikan dengan kemampuan dan usia masingmasing siswa. Media pembelajaran yang sering digunakan oleh siswa yaitu fasilitas umum untuk diskusi dalam kelas besar. Dalam pelaksanaan pembelajaran yang menjadi keunggulan Ananda Mentari Playgroup and kindergarten adalah adanya kegiatan eksplorasi secara khusus yang terjadwal dalam program pembelajaran. Kegiatan eksplorasi yang dilaksanakan menggunakan berbagai metode pembelajaran yang menarik dan menggunakan bahasa Inggris total sebagai pengantar kegiatan belajar sehingga membuat anak menjadi lebih senang mengikuti kegiatan.

3. Evaluasi pembelajaran siswa dilakukan dengan cara mengisi checklist dan anekdot. Evaluasi perkembangan dilaksanakan setiap awal dan akhir semester dengan memuat aspek fisik, emosi, sosial, kognitif, moral dan bahasa. Sedangkan evaluasi pembelajaran siswa dilakukan setiap minggu, setiap tiga bulan dan setiap enam bulan memuat aspek perkembangan kognitif, sosialemosional, moral-karakter, seni, bahasa, dan motorik.

Berdasarkan hasil penelitian yang telah dilaksanakan di Ananda Mentari Playgroup and kindergarten, sebagai bentuk rekomendasi kepada pihak yang terlibat dalam program pembelajaran dalam lingkungan berbahasa Inggris maka peneliti menyarankan beberapa hal sebagai berikut:

1) Bagi lembaga, adanya pembukuan rancangan program pembelajaran yang sistematis dapat mempermudah sekolah untuk melakukan evaluasi dan penilaian terhadap pelakasanaan pembelajaran.

2) Bagi sekolah lain, penerapan pembelajaran dalam bahasa Inggris di Ananda Mentari Playgroup and kindergarten dapat dijadikan referensi untuk melakukan pembelajaran dengan jenis kegiatan yang dapat memaknai penggunaan bahasa Inggris dalam komunikasi.

\section{DAFTAR PUSTAKA}

Diakses pada 15 Februari 2019 dari http://ejournal.upi.edu/index.php/cak rawaladini/article/download/10521/6 505 .

Eva, R. N. (2015). Pembelajaran bahasa inggris pada anak usia dini di sekolah alam exellentia pameksan madura. Jurnal OKARA. Vol. 1. Diakses pada 14 Februari 2019 dari http://ejournal.stainpamekasan.ac.id/i ndex.php/okara/article/download/582/564.

Hurlock, E. B. (2011). Psikologi perkembangan: suatu pendekatan sepanjang rentang kehidupan. Jakarta: Erlangga.

Moeslichatoen R. (2004). Metode pengajaran di taman kanak-kanak. Jakarta:PT Rineka Cipta.

Muafiah, E. (2016). Strategi pembelajaran multiple intelligences di TK/RA Ponorogo. Jurnal

ThufuLA. Vol. 4. No. 1. Diakses pada 30 Januari 2019 dari

https://www.researchgate.net/publica

tion/329780143_STRATEGI_PEMBELAJARAN_MULTIPLE_INTELLI GENCES_DI_TKRA_PONOROGO/download.

Nurbiana, D., dkk. (2007). Metode pengembangan bahasa (hakikat perkembangan bahasa anak). Semarang: IKIP Veteran.

Otto, Beverly. (2015). Perkembangan bahasa pada anak usia dini. Jakarta: Prenandamedia Group. 
Paramita Desintya. (2015). Upaya Meningkatkan Kemampuan Bahasa Inggris Anak Kelompok B dengan Menggunakan Strategi Pembelajaran Pesan Berantai di TK Pertiwi III Sawahan, Ngemplak, Boyolali. Skripsi, dipublikasikan Universitas Muhammadiyah Surakarta.

Purba, A. (2013). Peranan lingkungan bahasa dalam pemerolehan bahasa kedua. Jambi: FKIP Universitas Jambi.

Santrock, J. W. (2007). Perkembangan anak jilid 1 edisi kesebelas. Jakarta: PT.Erlangga.

Sugiyono. (2010). Metode penelitian kuantitatif kualitatif dan R\&D. Bandung: CV Alfabeta.

Suhartono. (2005). Pengembangan keterampilan bicara anak usia dini. Jakarta: Departeman Pendidikan Nasional.

Sujud, A. (1979). Pengantar administrasi pendidikan. Yogyakarta: FKIP IKIP.

Suryana, D. (2016). Pendidikan anak usia dini: stimulasi dan aspek perkembangan anak. Jakarta: Kencana.

Suyadi. (2010). Konsep dasar PAUD. Bandung: Remaja Rosdakarya.

Tirtaraharja \& La Sulo. (2005). Pengantar pendidikan. Jakarta: Rineka Cipta.

Wina, S. (2009). Penelitian tindakan kelas. Jakarta: Prenada Media Group.

Winti, A. (2015). "Should I Speak in English All the Time?" Teacher's Talk pada Pengenalan Bahasa Inggris bagi Anak Usia Dini. Jurnal Cakrawala Dini. Vol. 5. No. 2.

Wuryani, T. A. (2016). Pembelajaran anak usia dini berbasis multiple intelligences di TK Tunas Harapan Tambakrejo Ngaglik Sleman. Jurnal Pendidikan Madrasah. Vol. 1. No. 2. Diakses pada 30 Januari 2019 dari http://ejournal.uin-suka.ac.id/tarbiyah/index.php/JPM/ar ticle/download/1211/1104/.

Yuliani, N., \& Sujiono, B. (2010). Bermain kreatif berbasis kecerdasan jamak. Jakarta: Indeks 